\title{
An osteogenesis-related transcription factor, core-binding factor A1, is constitutively expressed in the chondrocytic cell line TC6, and its expression is upregulated by bone morphogenetic protein-2
}

\author{
Y Takazawa, K Tsuji, A Nifuji, H Kurosawa ${ }^{1}$, Y Ito $^{2}$ and $\mathbf{M}$ Noda \\ Department of Molecular Pharmacology, Medical Research Institute, Tokyo Medical and Dental University, Tokyo, Japan \\ ${ }^{1}$ Department of Orthopedic Surgery, Juntendo University, Tokyo, Japan \\ ${ }^{2}$ Department of Viral Oncology, Institute for Virus Research, Kyoto University, Kyoto, Japan \\ (Requests for offprints should be addressed to M Noda, Department of Molecular Pharmacology, Medical Research Institute, Tokyo Medical and Dental \\ University, 3-10, Kanda-Surugadai 2-Chome, Chiyoda-ku, Tokyo, 101, Japan; Email: noda.mph@mri.tmd.ac.jp)
}

\begin{abstract}
Core-binding factor A1 (Cbfa1), also called Pebp2 $\alpha$ A/ AML3, is a transcription factor that belongs to the runtdomain gene family. Cbfa1-deficient mice are completely incapable of both endochondral and intramembranous bone formation, indicating that $\mathrm{Cbfa} 1$ is indispensable for osteogenesis. Maturation of chondrocytes in these mice is also disorganized, suggesting that Cbfa1 may also play a role in chondrogenesis. The aim of this study was to examine the expression and regulation of Pebp2 $\alpha \mathrm{A} /$ AML3/Cbfa1 expression in the chondrocyte-like cell line, TC6. Northern blot analysis indicated that Cbfa $1 \mathrm{mRNA}$ was constitutively expressed as a $6.3 \mathrm{~kb}$ message in TC6 cells and the level of Cbfa1 expression was enhanced by treatment with bone morphogenetic protein-2 (BMP2) in a time- and dose-dependent manner. This effect was blocked by an RNA polymerase inhibitor, 5,6-dichloro-
\end{abstract}

$1-\beta$-D-ribofuranosylbenzimidazole, but not by a protein synthesis inhibitor, cycloheximide. Western blot analysis of the cell lysates using polyclonal antibody raised against Cbfa1 indicated that BMP2 treatment increased the Cbfa1 protein level in TC6 cells. In TC6 cells, BMP2 treatment enhanced expression of alkaline phosphatase and type I collagen mRNAs but suppressed that of type II collagen mRNA. In addition to TC6 cells, Cbfa 1 mRNA was also expressed in primary cultures of chondrocytes and BMP2 treatment enhanced Cbfa 1 mRNA expression in these cells similarly to its effect on TC6 cells. These data indicate that the Pebp2 $\alpha$ A/AML3/Cbfa1 gene is expressed in a chondrocyte-like cell line, TC6, and its expression is enhanced by treatment with BMP.

Journal of Endocrinology (2000) 165, 579-586

\section{Introduction}

Polyoma enhancer-binding protein (Pebp2)/core-binding factors (Cbf) belong to a family of transcription factors that form the heterodimeric proteins of two unrelated subunits, comprising of a DNA-binding $\alpha$ subunit and a non-DNAbinding $\beta$ subunit (Ogawa et al. 1993a, Wang et al. 1993, Ito \& Bae 1997). Pebp2 $\alpha /$ Cbfa contains a domain homologous to the Drosophila segmentation gene, runt. Three runt-related genes (Pebp2aA/AML3/Cbfa1, PebpP2aB/ AML1/Cbfa2, and Pebp2aC/AML2/Cbfa3) have been identified, to date, as members of this family (Bae et al. 1993, 1995, Ogawa et al. 1993b, Wang et al. 1993, Levanon et al. 1994, Wijmenga et al. 1995). Cbfa1 is involved in the regulation of $\mathrm{T}$ cell gene expression (Wang \& Speck 1992) and Cbfa2 is homologous to the human AML-1 gene identified during a study on acute myeloid leukemia (Meyers et al. 1993, Wang et al. 1996). Pebp2as/ Cbfas form heterodimers with a non-DNA binding factor,
Pebp $2 \beta / \mathrm{Cbfb}$ and this heterodimerization enhances the DNA binding and transactivation activities of Pebp2as/ Cbfas in vitro (Ogawa et al. 1993b, Wang et al. 1993, Ito \& Bae 1997).

Mice homozygous for the mutation on the Cbfa1 gene completely lack bones and die just after birth due to the inability to breath. In these mice, mature osteoblasts are hardly observed, indicating that Cbfa1 plays a critical role in the regulation of osteoblastic differentiation (Komori et al. 1997). On the other hand, heterozygous mice show specific bone defects that recapitulate the phenotype of the human skeletal disorder named cleidocranial dysplasia (CCD) (Otto et al. 1997) and, in fact, Cbfa1 mutations are associated with human CCD (Mundlos et al. 1997) as well. While Cbfa1 plays an essential role in osteoblastic differentiation and most cartilaginous primordial tissues can be observed in Cbfa1 knockout mice, the maturation of chondrocytes also appears to be disorganized in Cbfa1deficient mice (Komori et al. 1997). In these mice, 
chondrocyte differentiation is impaired around the time of appearance of prehypertrophic chondrocytes in part of the cartilage tissues, although hypertrophic chondrocytes can be observed in the skeletons, including tibia, fibula, radius and ulna. Neither vascular nor mesenchymal cell invasion is observed in calcified cartilage, suggesting that Cbfa1 may play a role in chondrocyte differentiation, although there is no information regarding the expression and regulation of $\mathrm{Cbfa} 1$ in chondrocytes in culture.

In the present paper, we show that $\mathrm{Cbfa} 1$ is expressed at a low level in the chondrocyte-like cell line, TC6, which is derived from knee articular cartilage of transgenic mice harboring SV40 large T-antigen gene (Mataga et al. 1996), and that Cbfa1 expression is upregulated by bone morphogenetic protein-2 (BMP2) treatment. Furthermore, Cbfa1 is also expressed in the primary cultures of chondrocytes and is upregulated by treatment with BMP2.

\section{Materials and Methods}

\section{Reagents}

Human recombinant BMP2 was a kind gift from J Wozney (Genetics Institute, Cambridge, MA, USA). Recombinant human transforming growth factor (TGF)$\beta 1$ and insulin-like growth factor (IGF) were purchased from R\&D Systems (Minneapolis, MN, USA).

\section{Cell cultures}

TC6 cells were established using the cells derived from the articular cartilage of the distal ends of femora of 2-monthold transgenic mice (C57BL/6J mouse) harboring a tsSV40 large T-antigen gene as described previously (Mataga et al. 1996). The cells express cartilage specific genes, such as type II collagen, aggrecan and link protein and the cells also retain their expression of cartilaginous phenotypes in an in vivo environment (Takazawa et al. 1999). For maintenance, the cells were cultured as described previously (Matage et al. 1996) at $33^{\circ} \mathrm{C}$ in $\alpha$-minimum essential medium ( $\alpha$-MEM; Sigma Chemical Co., St Louis, MO, USA) supplemented with $0.5 \%$ fetal bovine serum (FBS; GIBCO BRL, Gaithersburg, MD, USA) in a humidified atmosphere of $5 \% \mathrm{CO}_{2}$. During experiments, TC6 cells were plated at $1 \cdot 8 \times 10^{4} \mathrm{cells} / \mathrm{cm}^{2}$ (Costar, Cambridge, MA, USA) and were cultured in $\alpha$-MEM supplemented with $0.5 \%$ FBS at $33^{\circ} \mathrm{C}$. After reaching subconfluency, the media were replaced with fresh ones supplemented with $0 \cdot 1 \%$ FBS containing BMP2 or other agents.

Primary chondrocytes were prepared from the rib cartilages of 1-day-old ICR mice. The rib cartilages were digested with $3 \mathrm{mg} / \mathrm{ml}$ collagenase in Dulbecco's minimum essential medium (DMEM; GIBCO BRL) for $30 \mathrm{~min}$ at $37^{\circ} \mathrm{C}$, rinsed with phosphate-buffered saline and then digested with $3 \mathrm{mg} / \mathrm{ml}$ collagenase in DMEM at $37{ }^{\circ} \mathrm{C}$ in the atmosphere of $5 \% \mathrm{CO}_{2}$ for $5 \mathrm{~h}$, as previously described (Lefebvre et al. 1994). An average of $4 \times 10^{6}$ chondrocytes was obtained per mouse. Cells were plated at $0 \cdot 8 \times 10^{5} \mathrm{cells} / \mathrm{cm}^{2}$ (Costar) and were cultured in DMEM supplemented with antibiotics (penicillin $(50 \mathrm{U} / \mathrm{ml}$ ) and streptomycin $(50 \mu \mathrm{g} / \mathrm{ml})$; GIBCO) and 10\% FBS. After 4 days in culture, the media were replaced with fresh ones with or without BMP2.

\section{$R N A$ preparation and Northern blot analysis}

Total cellular RNA was extracted according to the acid guanidium (isothiocyanate-phenol-chloroform) method (Chomczynski \& Sacchi 1987). Aliquots of $10 \mu \mathrm{g}$ of the total RNA/lane were fractionated in agarose gel $(1 \%$ agarose, $20 \mathrm{mmol} / 1 \mathrm{MOPS} \mathrm{pH} 7 \cdot 0,0.5 \mathrm{mmol} / 1$ EDTA, $0.66 \mathrm{~mol} / \mathrm{l}$ formaldehyde) and then transferred onto nylon filters (Gene Screen; NEN Research Products, Boston, MA, USA) by electroblotting. The filters were prehybridized for 3-7 days at room temperature. A NcoI fragment of murine Pebp2 $\alpha \mathrm{A} / \mathrm{AML} 3 / \mathrm{Cbfa} 1 \mathrm{cDNA}$, which contains almost all of the C-terminal part of the coding region (1294-2568 bp Pebp2 $\alpha$ A/Cbfa1 cDNA) was labeled with ${ }^{32} \mathrm{P}$-deoxycytidine triphosphate using the BcaBEST random primer labeling kit (Takara Shuzo Co. Ltd, Tokyo, Japan) and was used for hybridization. Hybridization was performed at $42{ }^{\circ} \mathrm{C}$ for $24 \mathrm{~h}$ in a fresh hybridization buffer containing $3 \times 10^{6}$ c.p.m. $/ \mathrm{ml}$ of the labeled probe. Filters were washed in $1 \times \mathrm{SSC}-0 \cdot 1 \%$ SDS three times at room temperature for $5 \mathrm{~min}$ each, followed by rinsing for $20 \mathrm{~min}$ in $0.5 \times \mathrm{SSC}, 0 \cdot 1 \% \mathrm{SDS}$ at $60{ }^{\circ} \mathrm{C}$. The filters were subjected to autoradiography using X-ray films (Fuji Photo Film Co., Minamiashigara, Japan) and intensifying screens (New England Nuclear-DuPont, Boston, MA, USA) at $-80{ }^{\circ} \mathrm{C}$ for several days. Glyceraldehyde phosphate dehydrogenase (GAPDH) was used as the control. The bands in the Northern blot autoradiograms were quantitated by densitometry using a laser densitometer (Zero D Scan Image Analysis System), and each value was normalized against that of the GAPDH band in the corresponding lane. The normalized values obtained were used to calculate fold induction.

\section{Western blot analysis}

For Western blot analysis, TC6 cells grown to subconfluence in $145 \mathrm{~cm}^{2}$ dishes were cultured in modified $\alpha$-MEM medium with or without BMP2 at $500 \mathrm{ng} / \mathrm{ml}$ for $24 \mathrm{~h}$. The cells were then lysed in a buffer containing 0.0625 M Tris- $\mathrm{HCl}, 2 \%$ SDS, 10\% glycerol, 5\% mercaptoethanol and $0 \cdot 001 \%$ Bromophenol blue (BPB). The protein concentration was determined according to the method of Bradford (1976), and $10 \mu \mathrm{g}$ of each sample was separated by $15 \%$ SDS-PAGE (Laemmli 1970). The 
proteins were electrophoretically transferred to nitrocellulose filters (Protran Nitrocellulose; S \& S, Dassel, Germany) as described previously (Burnette 1981). The filters were then blocked for $2 \mathrm{~h}$ in 3\% non-fat dried milk in Tris-buffered saline and transferred proteins were incubated for $1 \mathrm{~h}$ in the presence of 1:500 dilution of polyclonal antibody raised against Cbfa1 (Y Ito, Kyoto University, Kyoto, Japan). The proteins on the filters were visualized by using an ECL-Plus Western blotting detection system (Amersham) as follows. The filters were first incubated with biotinylated anti-rabbit IgG (Vector Laboratories) and then the coloring was developed using 0.045 units $3,3^{\prime}$-diaminobenzidine tetrahydrochloride in $0.1 \mathrm{M}$ Tris- $\mathrm{HCl}$, pH 7.5, containing $0.03 \% \mathrm{H}_{2} \mathrm{O}_{2}$. As a control for protein loading, the same aliquots of proteins loaded in parallel gels were stained with Coomassie Brilliant Blue G 250 (Fluka Chemie AG CH-9471 Buchs, Germany).

\section{Statistical analysis}

Statistical evaluations of the data were conducted by using Student's $t$-test for per-comparison analysis. The data are presented as means \pm S.D. The results obtained from two to four independent experiments were analyzed.

\section{Results}

We first examined whether Cbfa1 is expressed in the chondrocytic cell line, TC6 cells. Northern blot analysis indicated that Cbfa 1 mRNA is constitutively expressed as a $6.3 \mathrm{~kb}$ message in TC6 cells (Fig. 1A, control). The level of Cbfa1 expression was enhanced by treatment with $500 \mathrm{ng} / \mathrm{ml} \mathrm{BMP2} \mathrm{(Fig.} \mathrm{1A).} \mathrm{Treatment} \mathrm{with} \mathrm{IGF-I} \mathrm{or}$ TGF- $\beta$ did not enhance the expression of Cbfa1 (Fig. 1B), indicating that BMP specifically enhanced the expression of Cbfa1. GAPDH levels served as control (Fig. 1A and B).

The time-course of the effect of BMP2 is shown in Fig. 2. BMP2 treatment upregulated $\mathrm{Cbfa} 1 \mathrm{mRNA}$ expression within $12 \mathrm{~h}$ and this effect lasted at least up to $48 \mathrm{~h}$ in TC6 cells (Fig. 2). TC6 cells were also treated for $24 \mathrm{~h}$ with BMP2 at various concentrations ranging from 50 to $500 \mathrm{ng} / \mathrm{ml}$. The BMP2 effect on Cbfa1 mRNA level was dose-dependent, maximal at $500 \mathrm{ng} / \mathrm{ml}$ (Fig. 3). The abundance of GAPDH mRNA was not affected by BMP2, indicating the specificity of the effect of BMP2 on Cbfa1 gene expression.

To investigate the mode of BMP2 action in the regulation of Cbfa1 gene expression, the cells were treated for $24 \mathrm{~h}$ with BMP2 in the presence or absence of inhibitors for transcription or protein synthesis. As shown in Fig. 4, we first analyzed the effect of BMP2 on Cbfa1 mRNA levels in the presence of 5,6-dichloro-1- $\beta$ D-ribofuranosylbenzimidazole (DRB) which inhibits mRNA synthesis, and found that BMP2 enhancement of

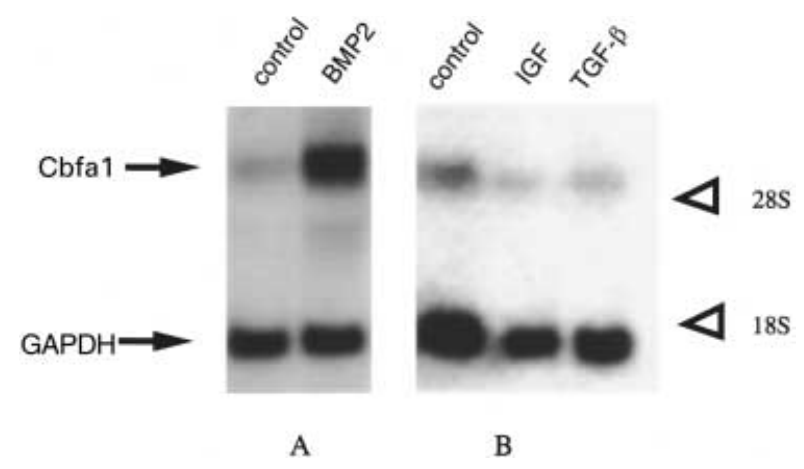

Figure 1 Cbfa 1 expression and its regulation by BMP2 and other agents in TC6 cells. TC6 cells at subconfluence were treated for $24 \mathrm{~h}$ with (A) BMP2 (500 ng/ml) and (B) TGF- $\beta(2 \mathrm{ng} / \mathrm{ml})$ and IGF-I $(50 \mathrm{ng} / \mathrm{ml})$. Total RNA $(10 \mu \mathrm{g} /$ lane) was fractionated on $1 \%$ agarose gel and Northern blot analysis was conducted to examine the Cbfa1 level, as described in Materials and Methods. GAPDH was used as control. The data represent one of three independent experiments with similar results. Arrows and arrowheads indicate the positions for Cbfa1, GAPDH, 28S and $18 \mathrm{~S}$ rRNAs. The relative Cbfa1 mRNA levels normalized against GAPDH mRNA levels for control and BMP2 were 1 and $2 \cdot 23$ respectively in (A). The relative Cbfa1 mRNA levels normalized against GAPDH mRNA levels for control, TGF- $\beta$ and IGF-I were $1,0.34$ and 0.22 respectively in (B).

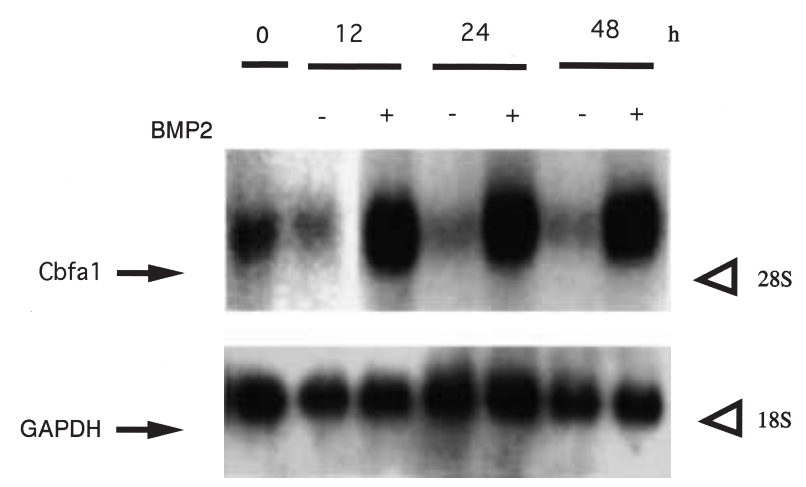

Figure 2 Time-course of the effects of BMP2 on the levels of Cbfa1 mRNA in TC6 cells. TC6 cells at subconfluence were cultured for the indicated periods of time (hours) in the absence $(-)$ or presence $(+)$ of $500 \mathrm{ng} / \mathrm{ml}$ BMP2. Total RNA $(10 \mu \mathrm{g} /$ lane $)$ was prepared as described in Materials and Methods and subjected to Northern blot analysis. The same filters were hybridized with ${ }^{32} \mathrm{P}$-labeled $\mathrm{Cbfa} 1$ and then GAPDH probes later. The data represent one of three independent experiments with similar results. Arrows and arrowheads indicate the positions for Cbfa1, GAPDH, $28 \mathrm{~S}$ and $18 \mathrm{~S}$ RNAs. The relative Cbfa1 mRNA levels normalized against GAPDH mRNA levels for 0-h control, 12-h control, 12-h BMP2, 24-h control, 24-h BMP2, 48-h control and 48-h BMP2 were 1, 1.19, 2.25, 0.56, 1.28, 1.42 and $2 \cdot 28$ respectively.

the levels of Cbfa1 mRNA was blocked by DRB (Fig. 4A). The BMP2 enhancement of Cbfa1 mRNA levels was still observed in the presence of a protein synthesis inhibitor, cycloheximide, indicating the direct effect of 


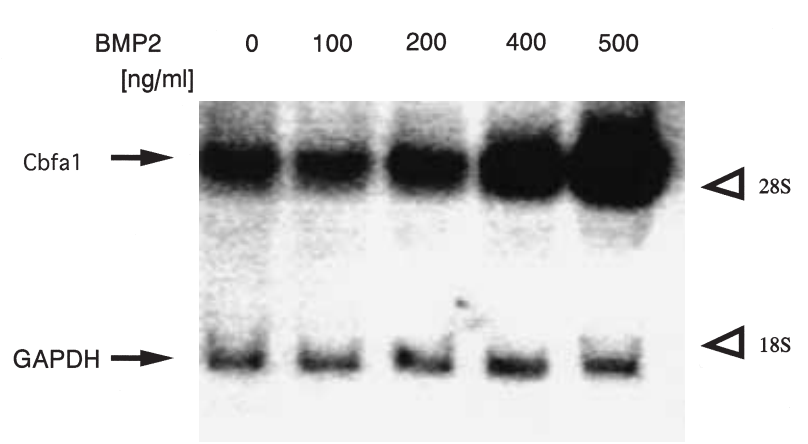

Figure 3 Dose-dependent effects of BMP2 on the levels of Cbfa1 mRNA in TC6 cells. TC6 cells at subconfluence were treated for $24 \mathrm{~h}$ with BMP2 at various concentrations ranging from 50 to $500 \mathrm{ng} / \mathrm{ml}$. Total RNA $(10 \mu \mathrm{g} /$ lane) was fractionated on $1 \%$ agarose gel and Northern blot analysis was conducted to examine the Cbfa1 level as described in Materials and Methods. GAPDH was used as the control. The data represent one of three independent experiments with similar results. Arrows and arrowheads indicate the positions for Cbfa1, GAPDH, 28S and $18 \mathrm{~S}$ rRNAs. The relative Cbfa1 mRNA levels normalized against GAPDH mRNA levels for control, 100, 200, 400 and $500 \mathrm{ng} / \mathrm{ml}$ BMP2 were $1,1 \cdot 08,1 \cdot 14,1 \cdot 20$ and 1.77 respectively.

BMP2 on Cbfa1 gene expression without requirement for new protein synthesis (Fig. 4B).

To examine whether the effect of BMP2 on Cbfa1 mRNA expression is translated into Cbfa1 protein levels, TC6 cells were treated with BMP2 at $500 \mathrm{ng} / \mathrm{ml}$ for $24 \mathrm{~h}$ and Western blot analysis was conducted. We found that treatment with BMP2 enhanced the level of Cbfa1 protein, which migrated as a $65 \mathrm{kDa}$ band (Fig. $5 \mathrm{~A}$ ). In addition to the $65 \mathrm{kDa}$ band, Western blot analysis indicated induction of 53 and $75 \mathrm{kDa}$ bands, though the natures of these bands have not yet been identified. These bands were not recognized by non-immune antiserum. As a control for protein loading, the same aliquots of proteins used for the Western blot were loaded in the parallel gels and Coomassie Brilliant Blue staining indicated similar levels of the proteins in each of the lanes (Fig. 5B).

We also examined the effects of BMP2 on the expression of genes encoding phenotype-related proteins in TC6 cells. BMP2 treatment enhanced alkaline phosphatase and type I collagen mRNA expression (Fig. 6A and B) while it suppressed type II collagen mRNA expression (Fig. 6C) in these cells.

While TC6 cells are derived from cartilage, their response to BMP could be different from authentic chondrocytes since TC6 cells harbor SV40 large T-antigen gene. We therefore examined whether Cbfa1 was expressed in chondrocytes freshly isolated from the rib cartilage of normal mice. In the Northern blot analysis using RNAs prepared from primary cultures of chondrocytes, Cbfa 1 mRNA was expressed as a $6.3 \mathrm{~kb}$ message in these chondrocytes and its level was enhanced by treatment with $500 \mathrm{ng} / \mathrm{ml} \mathrm{BMP2} \mathrm{(Fig.} \mathrm{7A).} \mathrm{BMP2} \mathrm{treatment}$ also enhanced alkaline phosphatase mRNA expression in these cells (Fig. 7B).

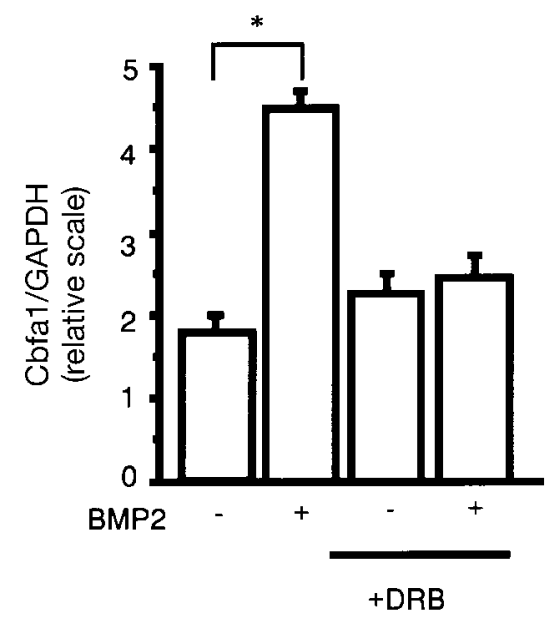

A

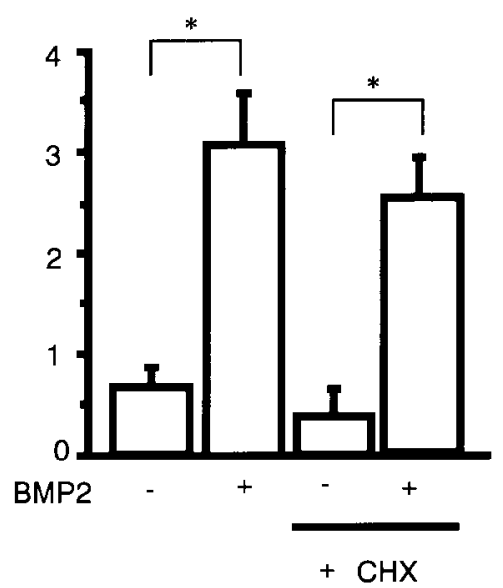

B

Figure 4 Effects of DRB and cycloheximide on BMP2-induced enhancement of Cbfa1 mRNA in TC6 cells. TC6 cells at subconfluence were treated with vehicle $(-)$ or $500 \mathrm{ng} / \mathrm{ml} \mathrm{BMP2} \mathrm{(+)} \mathrm{for} 24 \mathrm{~h}$ in the presence or absence of (A) $0 \cdot 2 \mu \mathrm{g} / \mathrm{ml}$ DRB or (B) $20 \mu \mathrm{g} / \mathrm{ml}$ cycloheximide (CHX). Total RNA was isolated as described in Materials and Methods and was subjected to Northern blot analysis. Quantitation of Cbfa1 mRNA levels was conducted by using a densitometer and the values obtained were normalized against those of GAPDH mRNA levels. Data were obtained from three independent experiments and are presented as means \pm S.D. ${ }^{*} P<0 \cdot 05$. There was no difference between the vehicle and $B M P 2$ in the presence of DRB (A). 


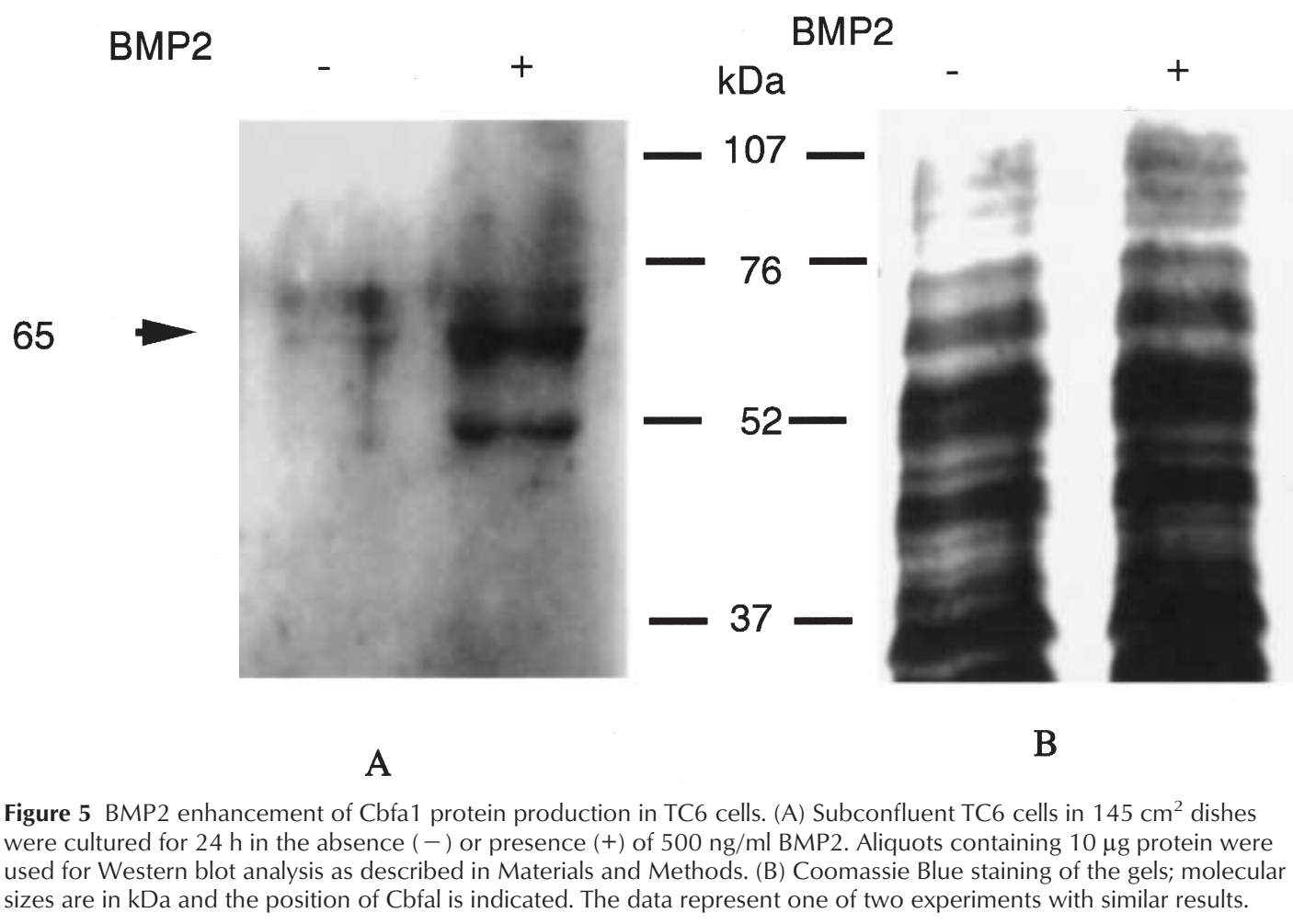

\section{Discussion}

Our present study demonstrates that Cbfa 1 mRNA is constitutively expressed in the chondrocyte-like cell line, TC6, and that it is a specific target of BMP2 action.
Furthermore, we also showed that Cbfa1 is expressed in primary cultures of chondrocytes, and BMP2 again enhances the expression of Cbfa1 in these cells. Mesenchymal cell differentiation into specific lineages of cells, including chondrocytes, is under the control of certain sets

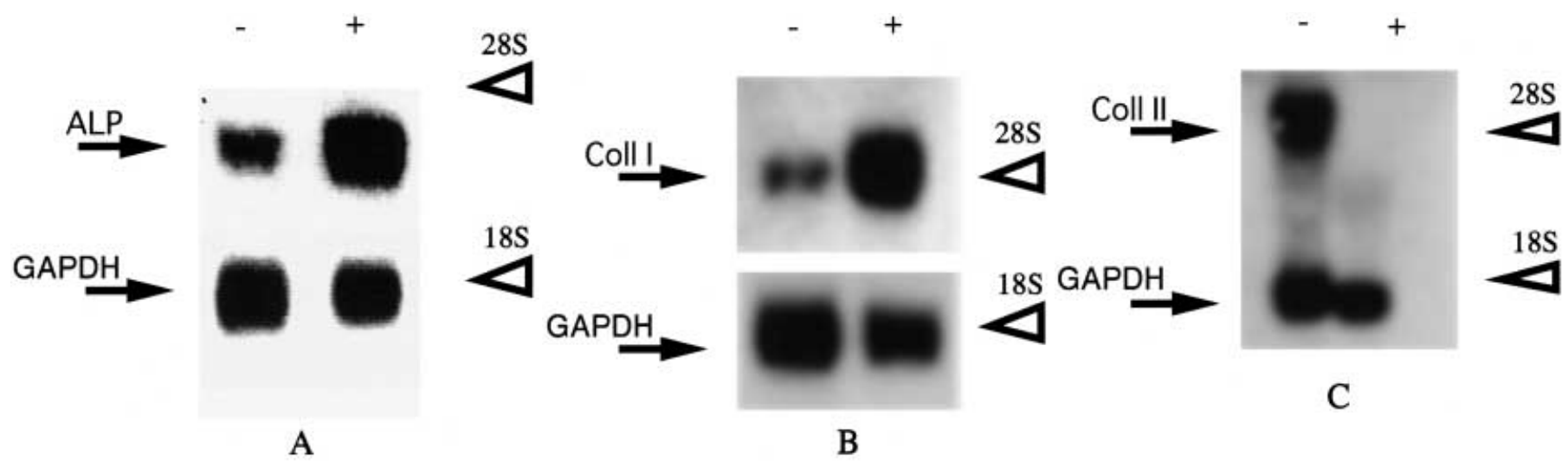

Figure 6 Effects of BMP2 on the expression of alkaline phosphatase and collagen genes in TC6 cells. TC6 cells at subconfluence were treated for $24 \mathrm{~h}$ with BMP2 $(500 \mathrm{ng} / \mathrm{ml})$. Total RNA $(10 \mu \mathrm{g} / \mathrm{lane})$ was fractionated on $1 \%$ agarose gel and Northern blot analysis was conducted to examine the (A) alkaline phosphatase (ALP), (B) type I collagen (Coll I) or (C) type II collagen (Coll II) mRNA levels, as described in Materials and Methods. GAPDH was used as the control. The data represent one of two independent experiments with similar results. Arrows and arrowheads indicate the positions for Cbfa1, GAPDH, 28S and 18S RNAs. The relative levels of alkaline phosphatase mRNA levels normalized against GAPDH mRNA levels for control and 500 ng/ml BMP2 were 1 and 1.93 respectively. The relative levels of the type I collagen mRNA normalized against GAPDH mRNA levels for control and $500 \mathrm{ng} / \mathrm{ml}$ BMP2 were 1 and 1.94 respectively. The relative levels of the type Il collagen mRNA normalized against GAPDH mRNA levels for control and $500 \mathrm{ng} / \mathrm{ml} \mathrm{BMP2}$ were 1 and $0 \cdot 26$ respectively. 


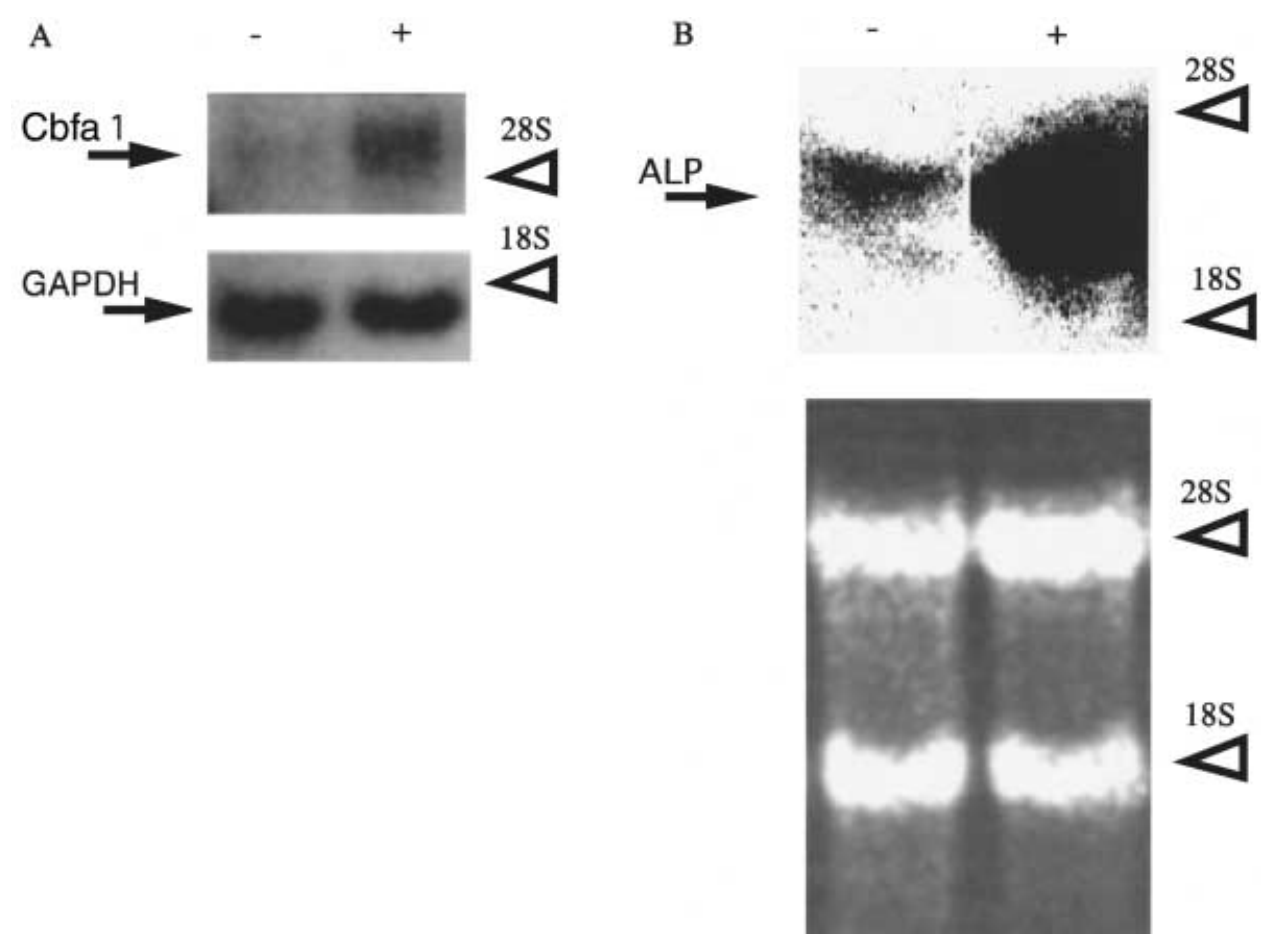

Figure 7 Cbfa1 gene expression and its regulation by BMP2 in primary cultures of chondrocytes. Primary cultures of chondrocytes were prepared as described in the Materials and Methods. The cells were treated for $24 \mathrm{~h}$ with BMP2 $(500 \mathrm{ng} / \mathrm{ml})$. Total RNA (10 $\mu \mathrm{g} / \mathrm{lane})$ was prepared, fractionated on $1 \%$ agarose gel and subjected to Northern blot analysis to examine (A) Cbfa1 and (B) alkaline phosphatase (ALP) expression and the effect of BMP2 on its expression. GAPDH was used as the control. The data represent one of two independent experiments with similar results. Arrows and arrowheads indicate the positions for $\mathrm{Cbfa} 1$, alkaline phosphatase, GAPDH, $28 \mathrm{~S}$ and $18 \mathrm{~S}$ rRNAs. The relative Cbfa1 mRNA levels normalized against GAPDH mRNA levels for control and $500 \mathrm{ng} / \mathrm{ml}$ BMP2 were 1 and 2.97 respectively. The relative alkaline phosphatase mRNA levels normalized against $28 \mathrm{~S}$ rRNA levels for control and $500 \mathrm{ng} / \mathrm{ml} \mathrm{BMP2}$ were 1 and 16.74 respectively.

of transcription factors (Aubin et al. 1993). Although Cbfa1 is a prerequisite for osteogenesis, it is expressed in chondrocytes as we have shown here and also in several non-osteoblastic cells, at least in culture. These observations support the previous notion that a relatively wide range of cell types are potentially capable of differentiating into osteoblasts if the cells are kept under certain appropriate conditions in vivo or in vitro.

Although bone is totally absent in Cbfa1 null mice, cartilage is mostly observed in limb and axial skeletons such as vertebrae. However, detailed examination of the chondrocytes revealed an alteration in their morphology. Our observations on the expression and BMP regulation of Cbfa1 suggest that Cbfa1 may play a certain role in chondrocytes per se as well. Observations on the minor change in chondrocytes compared with osteoblasts in Cbfa1 null mice suggest that lack of Cbfa1 could be compensated by, at least in part, another as yet unidentified transcription factor(s). Alternatively, the role of Cbfa1 in chondrocytes may be limited to specific stages of chondrocyte differentiation such as the hypertrophic stage of the cell. It may also be possible that, at least under culture conditions, certain fractions of chondrocytes could become undifferentiated and these cells could generate cells with relatively immature fibroblastic phenotypes, and thus are capable of differentiating into osteoblasts upon stimulation by certain signals such as BMP2.

The expression of osteoblast phenotype-related alkaline phosphatase and type I collagen genes in the chondrocytelike TC6 cells was enhanced by the treatment with BMP2, while expression of the chondrocyte-related type II collagen gene was suppressed. These observations suggest that BMP2 might suppress expression of the genes encoding cartilage-related phenotype and/or it might shift chondrocytic cells to become more osteoblast-like cells. Alternatively, BMP may promote maturation of chondrocytes. This possibility is still open, as alkaline phosphatase mRNA expression, a marker of both osteoblasts and hypertrophic chondrocytes, was enhanced by BMP in both TC6 cells and primary cultures of chondrocytes. However, we did not detect type X collagen expression even after BMP2 treatment (data not shown). Whether 
the upregulation of Cbfa1 by BMP2 causes such an alteration in the expression of phenotype-related genes needs further analysis. Our preliminary experiments indicated that the cells prepared from Cbfa1 knockout mice are unable to increase type I collagen mRNA expression even after treatment with BMP (data not shown).

It has been indicated that BMPs enhance expression of $\mathrm{Cbfa} 1$ in calvaria-derived osteoblast-enriched cells (Komori et al. 1997). BMPs also enhances expression of phenotype-related genes in osteoblast-like MC3T3-E1 cells (Hiraki et al. 1991), rat calvaria-derived osteoblastenriched cells (Vukicevic et al. 1989, Chen et al. 1991a) and osteoprogenitor cells (Yamaguchi et al. 1991). In addition, other studies have suggested that BMPs affect chondrogenesis as well (Carrington et al. 1991, Chen et al. 1991b, Hiraki et al. 1991, Iwasaki et al. 1994). These diverse results may be due to the differences in the responses to BMPs based on the difference in the sets of transcription factors and cofactors operating in the individual cellular backgrounds and/or under culture conditions.

The actions of BMP have been shown to be mediated via Sma+mad (Smad) and/or TGF $\beta$-activated kinase (TAK) systems in osteoblasts and fibroblasts actions. Whether similar adapter protein systems are operating in chondrocytes requires further elucidation of BMP signaling pathway in chondrocytes. The role of Cbfa1 in chondrocytes could be to balance the levels of expression of the genes in the skeletal cells, depending on which direction the cells differentiate into, although elucidation of the mechanisms of the tuning of this balance needs further investigations. In the process of fracture repair, it is thought that certain fractions of chondrocytes redifferentiate into osteoblasts directly. BMP2 regulates Cbfa1 during the healing process of fractures, the drugs or treatment targeted to enhance BMP as well as Cbfa1 expression would be beneficial for the healing of the fractures.

\section{Acknowledgements}

This research was supported by grants-in-aid received from the Japanese Ministry of Education (11152209, 11877357, 10044246, 10877223, 09307304), grants from Core Research for Evolutional Science and Technology of the Japan Science and Technology Corporation, a grant from the Research for the Future Program of the Japan Society for the Promotion of Science (96100205), and grants from the NASDA, Inamori Foundation and a grant from Cell Fate Modulation Research Unit.

\section{References}

Aubin JE, Turksen K \& Heersche JNM 1993 Osteoblastic lineage. In Cellular and Molecular Biology of Bone, pp 1-45. Ed. M Noda. London: Academic Press.

Bae S-C, Yamaguchi-Iwai Y, Ogawa E, Maruyama M, Inuzuka M, Kagoshima H, Shigesada K, Satake M \& Ito Y 1993 Isolation of Pebp $2 \alpha B$ cDNA representing the mouse homolog of human acute myeloid leukemia gene, AML1. Oncogene 8 809-814.
Bae S-C, Takahashi E, Zhang YW, Ogawa E, Shigesada K, Namba Y, Satake M \& Ito Y 1995 Cloning, mapping, and expression of $P E B P 2 \alpha C$, a third gene encoding the mammalian runt domain. Gene 159 245-248.

Bradford MM 1976 A rapid and sensitive method for the quantitation of microgram quantities of protein utilizing the principle of protein dye binding. Analytical Biochemistry 72 248-254.

Burnette WN 1981 Western blotting: electrophoretic transfer of proteins from sodium dodecyl sulfate-polyacrylamide gels to unmodified nitrocellulose and radiographic detection with antibody and radioiodinated protein A. Analytical Biochemistry 112 195-203.

Carrington JL, Chen P, Yanagishita M \& Reddi AH 1991 Osteogenin (bone morphogenetic protein-3) stimulates cartilage formation by chick limb bud cells in vitro. Developmental Biology 146 406-415.

Chen TL, Bates RL, Dudley A, Hammonds RG \& Ameno EP 1991 a Bone morphogenetic protein $2 \beta$ stimulation of growth and osteogenic phenotypes in rat osteoblast-like cells: comparison with TGF- $\beta_{1}$. Journal of Bone and Mineral Research 6 1387-1393.

Chen P, Carrington JL, Hammonds RG \& Reddi AH $1991 b$ Stimulation of chondrogenesis in limb bud mesoderm cells by recombinant human bone morphogenetic protein $2 \mathrm{~B}$ (BMP-2B) and modulation by transforming growth factor $\beta 1$ and $\beta 2$. Experimental Cell Research 195 509-515.

Chomczynski P \& Sacchi N 1987 Single-step method of RNA isolation by acid guanididium thioglycolate-phenol-chloroform extraction. Analytical Biochemistry 162 156-159.

Hiraki Y, Inoue H, Shigeno C, Sanma Y, Bentz H, Rosen DM, Asada A \& Suzuki F 1991 Bone morphogenic proteins (BMP-2 and BMP-3) promote growth and expression of the differentiated phenotype of rabbit chondrocytes and osteoblastic MC3T3-E1 cells in vitro. Journal of Bone and Mineral Research 6 1373-1385.

Ito Y \& Bae S-C 1997 The runt domain transcription factor, PEBP2/ $\mathrm{CBF}$, and its involvement in human leukemia. Oncogenes as Transcriptional Regulators 2 107-132.

Iwasaki M, Nakahara H, Nakase T, Kimura T, Takaoka K, Caplan AI \& Ono K 1994 Bone morphogenetic protein-2 stimulates osteogenesis but does not affect chondrogenesis in osteochondrogenic differentiation of periostium-derived cells. Journal of Bone and Mineral Research 9 1195-1204.

Komori T, Yagi H, Nomura S, Yamaguchi A, Sasaki K, Deguchi K, Shimizu Y, Bronson RT, Gao Y-H, Inada M, Sato M, Okamoto R, Kitamura Y, Yoshiki S \& Kishimoto T 1997 Target disruption of Cbfa1 results in a complete lack of bone formation owing to maturational arrest of osteoblasts. Cell 89 755-764.

Laemmli UK 1970 Cleavage of structural proteins during the assembly of the head bacteriophage T4. Nature 227 680-685.

Lefebvre V, Garofalo S, Zhou G, Metsaranta M, Vuorio E \& De Cromburgghe B 1994 Characterization of primary cultures of chondrocytes from type II collagen/ $\beta$-galactosidase transgenic mice. Matrix Biology 14 329-335.

Levanon D, Negureanu V, Bernstein Y, Bar-Am I, Avivi L \& Groner Y 1994 AML1, AML2, and AML3, the human members of the runt domain gene family: cDNA structure, expression, and chromosomal localization. Genomics 23 425-432.

Mataga N, Tamura M, Yanai N, Shinomura T, Kimata K, Obinata M \& Noda M 1996 Establishment of a novel chondrocyte-like cell line derived from transgenic mice harboring the temperature-sensitive simian virus 40 large T-antigen gene. Journal of Bone and Mineral Research 11 1646-1654.

Meyers S, Downing JR \& Hiebert SW 1993 Identification of AML-1 and the $(8 ; 21)$ translocation protein (AML-1/ETO) as sequencespecific DNA-binding proteins: the runt homology domain is required for DNA binding and protein-protein interactions. Molecular and Cellular Biology 13 6336-6345.

Mundlos S, Otto F, Mundlos C, Mulliken JB, Aylsworth AS, Albright S, Lindhout D, Cole WG, Henn W, Knoll JHM, Owen MJ, 
Mertelsmann R, Zabel BU \& Olsen BR 1997 Mutations involving the transcription factor CBFA1 cause cleidocranial dysplasia. Cell $\mathbf{8 9}$ 773-779.

Ogawa E, Inuzuka M, Maruyama M, Satake M, Naito-Fujimoto M, Ito Y \& Shigesada K 1993a Molecular cloning and characterization of Pebp2 $\beta$, the heterodimeric partner of a novel Drosophila runtrelated DNA binding protein PEBP2 $\alpha$. Virology 194 314-331.

Ogawa E, Maruyama M, Kagoshima H, Inuzuka M, Lu J, Satake M, Shigesada K \& Ito Y 1993 bEBP2/PEA2 represents a family of transcription factors homologous to the products of the Drosophila runt gene and human AML1 gene. Proceedings of the National Academy of Sciences of the USA 90 6859-6863.

Otto F, Thornell AP, Crompton T, Denzel A, Gilmour KC, Rosewell IR, Stamp GWH, Beddington RSP, Mundlos S, Olsen BR, Selby PB \& Owen MJ 1997 Cbfa1, a candidate gene for cleidocranial dysplasia syndrome, is essential for osteoblast differentiation and bone development. Cell 89 765-771.

Takazawa Y, Nifuji A, Mataga N \& Noda M 1999 Articular cartilage cells immortalized by a temperature sensitive mutant of SV 40 large $\mathrm{T}$ antigen survive and form cartilage tissue in articular cartilage environment. Journal of Cellular Biochemistry 75 338-345.

Vukicevic S, Luyten FP \& Reddi AH 1989 Stimulation of expression of osteogenic and chondrogenic phenotypes in vitro by osteogenin. Proceedings of the National Academy of Sciences of the USA $\mathbf{8 6}$ 8793-8797.
Wang S \& Speck NA 1992 Purification of core-binding factor, a protein that binds the conserved core site in murine leukemia virus enhancers. Molecular and Cellular Biology 12 89-102.

Wang S, Wang Q, Crute BE, Melnikova IN, Keller SR \& Speck NA 1993 Cloning and characterization of subunits of the T-cell receptor and murine leukemia virus enhancer core-binding factor. Molecular and Cellular Biology 13 3324-3339.

Wang Q, Stacy T, Miller JD, Lewis AF, Gu T-L, Huang X, Bushweller JH, Bories J-C, Alt FW, Ryan G, Liu PP, WynshawBoris A, Binder M, Marin-Padilla M, Sharpe AH \& Speck NA 1996 The $\mathrm{CBFb}$ subunit is essential for CBFa2 (AML1) function in vivo. Cell 87 697-708.

Wijmenga C, Speck NA, Dracopoli NC, Hofker MH, Liu P \& Collins FS 1995 Identification of a new murine runt domaincontaining gene, $\mathrm{Cbfa} 3$, and localization of the human homolog, CBFA3, to chromosome lp35-pter. Genomics 26 611-614.

Yamaguchi A, Katagiri T, Ikeda T, Wozney JM, Rosen V, Wang EA, Kahn AJ, Suda T \& Yoshiki S 1991 Recombinant human bone morphogenetic protein-2 stimulates osteoblastic maturation and inhibits myogenic differentiation in vitro. Journal of Cell Biology 113 681-687.

Received 23 December 1999

Accepted 20 January 2000 